\title{
SISTEM DETEKSI BANJIR SECARA DINI UNTUK MENGURANGI KERUGIAN KELOMPOK PETERNAK IKAN TAWAR DI DESA TEMULUS KECAMATAN MEJOBO KABUPATEN KUDUS
}

\author{
Muhammad Arifin \\ Fakultas Teknik, Program Studi Sistem Informasi \\ Universitas Muria Kudus \\ Email: arifin.m@umk.ac.id \\ Supriyono \\ Fakultas Teknik, Program Studi Sistem Informasi \\ Universitas Muria Kudus \\ Email: supriyono@umk.ac.id
}

\begin{abstract}
ABSTRAK
Desa Temulus merupakan desa yang memiliki potensi untuk menghasilkan hasil pertanian khususnya ikan tawar, dimana disana terdapat tambak-tambak yang telah dibuat oleh swasta maupun pemerintah. Peternak ikan tawar desa Temulus sering mengalami kerugian akibat banjir hal ini disebabkan karena informasi datangnya banjir terlambat sampai ke peternak. Penelitian ini bermaksud untuk menyelesaikan permasalahan yang dihadapi para peternak ikan tawar dimana penelitian ini mengusulkan desain alat deteksi banjir secara dini dengan menggunakan peralatan yang mudah didapat dan murah harganya. Langkah-langkah penelitian ini adalah proses analisa kebutuhan, perancangan, pembuatan, testing dan pemasangan alat. Desain alat deteksi banjir secara dini ini dapat dimanfaatkan oleh kelompok peternak ikan tawar di Desa Temulus Kecamatan Mejobo Kabupaten Kudus dengan harapan dapat mengurangi kerugian peternak ikan tawar akibat banjir. Penelitian ini juga dapat menjadi materi referensi bagi peneliti sejenis untuk mengembangkan alat yang lebih mutahir sesuai kebutuhan obyek penelitian dan dengan kemajuan teknologi yang ada.
\end{abstract}

Kata kunci: deteksi banjir dini, peternak ikan tawar.

\section{ABSTRACT}

Temulus is a village that has the potential to produce agricultural products, especially fresh fish, where there are many ponds that have been made by both private and public. Freshwater fish breeders Temulus village often suffered losses due to floods this was due to the flood of information too late to the breeder. This study intends to solve the problems facing freshwater fish farmers where this research proposes the design of flood early detection tools by using equipment that is available and cheap. The steps of this research is the process of needs analysis, design, manufacture, testing and installation of equipment. Design flood early detection tool can be used by groups of freshwater fish farmers in the village Temulus Mejobo District of Kudus in hopes of reducing the loss of fresh fish farmers due to flooding. This research could also be a kind of reference material for researchers to develop a tool that is more up to date in accordance with the needs of the object of research and new technology

Keywords: early flood detection, freshwater fish breeders.

\section{PENDAHULUAN}

Banjir merupakan bencana yang merugikan banyak pihak maupun kelompok, tidak terkecuali kelompok masyarakat yang memiliki usaha bisa terganggu aktifitasnnya sehingga mengalami kerugian [1]. Desa Temulus merupakan salah satu desa yang paling sering terkena bencana banjir, hal itu dikarenakan desa Temulus merupakan desa dengan dataran yang rendah. Dengan menjadi langganan banjir pada setiap tahunnya maka desa ini kurang produktif untuk pertanian, karena hanya sekali musim tanam yaitu pada musim kemarau.

Pada tahun 2012 desa Bupati Kudus atas nama pemerintah Kabupaten Kudus telah menjadikan desa Temulus sebagai desa kampung rawa, dimana desa tersebut dijadikan desa kawasan wisata kuliner dan perikanan dengan dibangunnya tambak ikan tawar seluas 7 hektar [2]. Pembangunan tambak tersebut menghabiskan biaya Rp 630 juta yang terbagi di dua desa yaitu 7 hektar di desa Temulus dan 2 hektar di 
desa Bulungcangkrin. Menurut Kepala Dinas Pertanian, Perikanan dan Kehutanan Kabupaten Kudus bahwa dana pembangunan tersebut berasal dari bantuan Gubernur Jawa tengah. Berawal dari pencanangan desa kampung rawa oleh pimpinan kabupaten Kudus pada tahun 2012, di tahun 2014 telah terbangun tambak ikan tawar seluas 47 hektar yang tersebar dibeberapa kecamatan di Kudus dengan jumlah penambak/peternak mencapai 70 Orang.

Informasi dari harian digital Suara Merdeka 07 Februari 2014 bahwa jutaan ekor ikan hanyut, petambak rugi milyaran rupiah[3], kerugian tersebut dialami oleh peternak ikan tawan termasuk peternak ikan tawar desa Temulus. Berdasarkan informasi tersebut permasalahan yang dihadapi oleh peternak ikan tawar pada desa Temulus adalah mengalami kerugian yang besar ketika tambak mereka tergenang banjir dikarenakan ikan yang ada didalam tambak banyak yang terlepas, meskipun telah dibangun tanggul yang cukup tinggi namun ketika banjir yang datang besar dan datangnya dengan tiba-tiba peternak tidak sempat menyelamatkan ikan-ikan didalam tambak mereka.

\section{RUMUSAN MASALAH}

Desa Temulus, yang secara administratif termasuk di kecamatan Mejobo, Kudus, Jawa Tengah, merupakan desa kampung rawa, sebagian penduduknya petani dan peternak ikan tawar. Di bidang peternak ikan tawar, permasalahan yang dihadapi adalah terjadi kerungian yang besar ketika banjir datang dengan tiba-tiba hal ini dikarenakan peternak ikan tawar tidak sempat menyelamatkan ikan didalam tambaknya.

Masalah-masalah utama yang dihadapi para peternak ikan tawar di desa Temulus ini adalah ketidak tahuan mereka tentang analisa, perancangan, pembangunan/pembuatan alat yang efektif dengan harga yang murah yang mampu menyelesaikan permasalah khususnya deteksi banjir secara dini.

\section{TINJAUAN PUSTAKA}

\subsection{Penelitian Terkait}

Deteksi banjir secara dini telah diteliti dan dikembangkan oleh banyak peneliti diantaranya adalah Dachlan S.H. dkk [4], Pratomo I. F. dan Priyanto A [5], penelitian yang dipublikasikan oleh Nugroho G.P. dkk [6]. selain dari peneliti-peneliti tersebut masih banyak lagi penelitian yang bertemakan deteksi banjir secara dini. Melihat hal tersebut maka teknologi akan deteksi banjir secara dini sangat dibutuhkan dan diterapkan terutama untuk membantu peternak ikan tawar dalam menghadapi permasalahan yang ada.

Teknologi yang akan digunakan adalah sebuah alat deteksi banjir secara dini, alat ini didisain untuk mengetahui tingkat ketinggian air dari tanah, alat yang digunakan ini merupakan karya sederhana tidak memerlukan peralatan yang mahal. Alat dan bahan yang digunakan tergolong murah dan mudah didapat, hal ini merupakan salah satu pertimbangan pembuatan alat, sehingga nantinya masyarakat dapat membuat sendiri dengan mudah dan murah.

\subsection{Landasan Teori}

\subsubsection{Deteksi Dini (Early Warning System)}

Terdapat dua pengertian deteksi dini yaitu menurut UNDP/UNISDR dan Peraturan Pemerintah Nomor 50 Tahun 2005 tanggal 16 November 2005 pasal 17 ayat 10

a. Menurut UNDP/UNISDR [7]

Suatu mekanisme yang berupa pemberian informasi secara tepat waktu dan efektif, melalui institusi yang dipilih, agar masyarakat/ individu di daerah rawan mampu mengambil tindakan menghindari atau mengurangi resiko dan mampu bersiap-siap untuk merespon secara efektif

b. Menurut Peraturan Pemerintah Nomor 50 Tahun 2005 tanggal 16 November 2005 pasal 17 ayat 10 [8] Upaya memberitahukan kepada warga yang berpotensi dilanda suatu masalah untuk menyiagakan mereka dalam menghadapi kondisi dan situasi suatu masalah

\subsubsection{Banjir}

Banjir adalah merupakan suatu keadaan sungai dimana aliran airnya tidak tertampung oleh palung sungai, karena debit banjir lebih besar dari kapasitas sungai yang ada. Secara umum penyebab terjadinya banjir dapat dikategorikan menjadi dua hal, yaitu karena sebab-sebab alami dan karena tindakan manusia [9]. Yang termasuk sebab alami diantaranya : 
a. Curah hujan

Pada musim penghujan curah hujan yang tinggi akan mengakibatkan banjir di sungai dan bilamana melebihi tebing sungai, maka akan timbul banjir atau genangan.

b. Pengaruh fisiografi

Fisiografi atau geografi fisik sungai seperti bentuk, dan kemiringan Daerah Pengaliran Sungai (DPS), kemiringan sungai, Geometri hidrolik (Bentuk penampang seperti lebar, kedalaman, potongan memanjang, material dasar sungai), lokasi sungai.

c. Erosi dan sedimentasi

Erosi di DPS berpengaruh terhadap kapasitas penampungan sungai, karena tanah yang tererosi pada DPS tersebut apabila terbawa air hujan ke sungai akan mengendap dan menyebabkan terjadinya sedimentasi. Sedimentasi akan mengurangi kapasitas sungai dan saat terjadi aliran yang melebihi kapasitas sungai dapat menyebabkan banjir.

d. Kapasitas sungai

Pengurangan kapasitas aliran banjir pada sungai disebabkan oleh pengendapan yang berasal dari erosi dasar sungai dan tebing sungai yang berlebihan, karena tidak adanya vegetasi penutup.

e. Pengaruh air pasang

Air laut memperlambat aliran sungai ke laut. Pada waktu banjir bersamaan dengan air pasang yang tinggi, maka tinggi genangan/banjir menjadi lebih tinggi karena terjadi aliran balik (back water)

Yang termasuk penyebab banjir akibat tindakan manusia diantaranya :

a. Perubahan kondisi daerah pengaliran sungai

Perubahan DPS seperti penggundulan hutan, usaha pertanian yang kurang tepat, perluasan kota dan perubahan tata guna lainnya dapat memperburuk masalah banjir karena berkurangnya daerah resapan air dan sediment yang terbawa ke sungai akan memperkecil kapasitas sungai yang mengakibatkan meningkatnya aliran banjir.

b. Kawasan kumuh

Perumahan kumuh yang terdapat di bantaran sungai merupakan penghambat aliran sungai.

c. Sampah

Pembuangan sampah di alur sungai dapat meninggikan muka air banjir karena menghalangi aliran.

\section{METODOLOGI}

Perancangan dan pembuatan alat deteksi banjir secara dini untuk mengurangi kerugian kelompok peternak ikan tawar di Desa Temulus Kecamatan Mejobo Kabupaten Kudus dengan langkah-langkah yang ditunjukkan pada gambar 1 .

Gambar 1 menjelaskan tentang langkah-langkah metodologi penelitian tentang deteksi banjir secara dini untuk mengurangi kerugian kelompok peternak ikan tawar di Desa Temulus Kecamatan Mejobo Kabupaten Kudus dimana pada langkah awal adalah proses analisa kebutuhan alat dengan melakukan observasi pada obyek penelitian dan studi pustaka tentang teknologi deteksi banjir. Pada langkah selanjutnya adalah proses perancangan alat dengan memperhatikan desai dan analisa kebutuhan bahar dimana pada langkah pertama dan kedua dengan memperhatikan pada masalah penelitian. Langkah ketiga adalah proses membangun alat yaitu proses pembuatan alat deteksi banjir kemudian dilajutkan dengan testing dilaboratorium dan lapangan sebelum proses pemasangan alat, dimana proses pemasangan alat merupakan langkah terahir dari proses penelitian ini. 


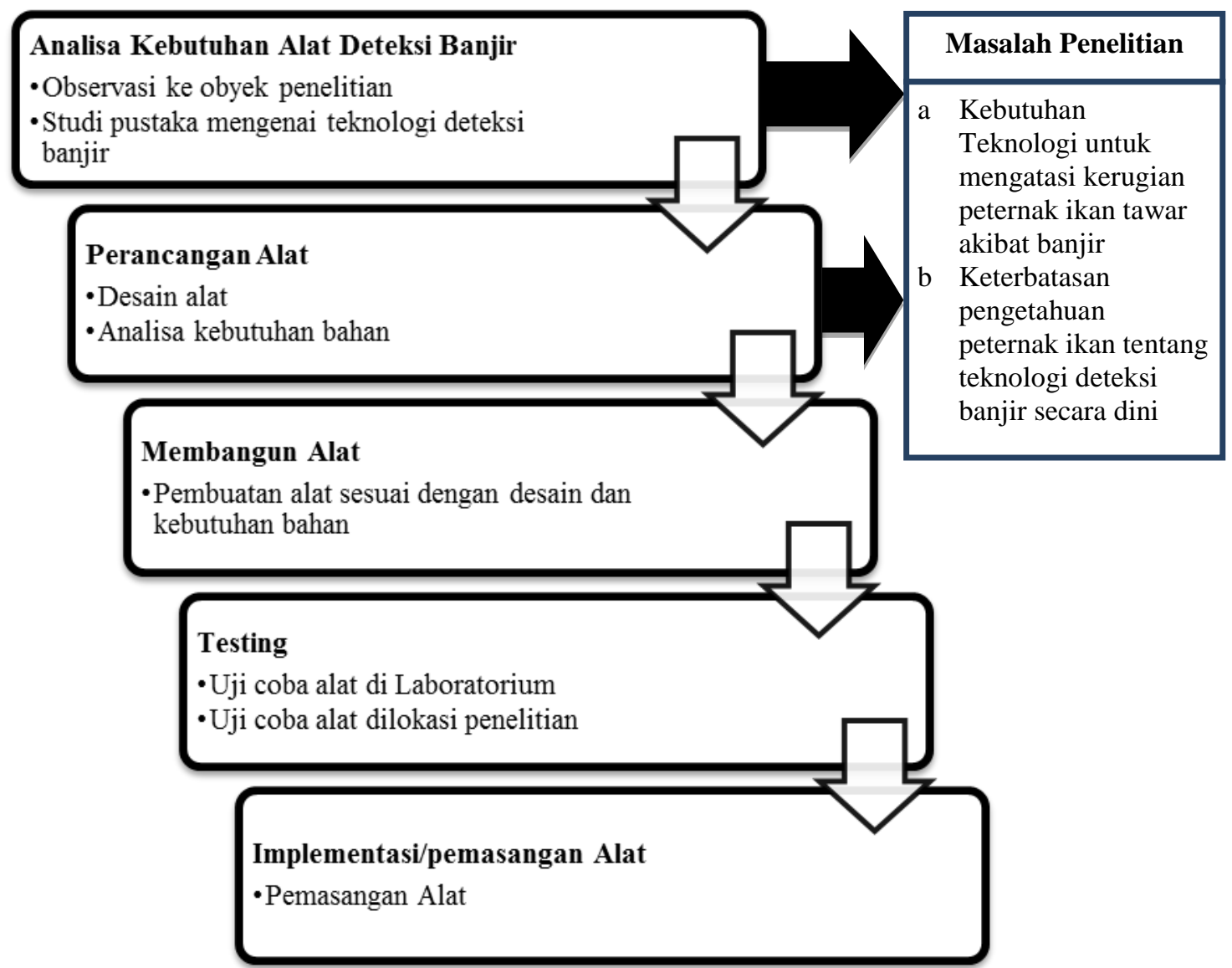

Gambar 1. Langkah-langkah penelitian

\section{HASIL DAN PEMBAHASAN}

Alat deteksi banjir secara dini ini bekerja berdasarkan tingkat ketinggian air, alat dipasang pada titik-titik yang dianggap mampu memberikan informasi banjir, alat ini akan memberikan informasi kepada pemilik tambak melalui alarm maupun sms, alat ini juga didisain dengan sumber energi dari tenaga surya dan tenaga listrik, untuk alat yang menggunakan tenaga surya nantinya akan dipasang pada titik yang jauh dari sumber listrik. Alat ini terbuat dari pipa pralon dan pipa besi, pipa pralon digunakan untuk sesor ketinggian air sedangkan pipa besi sebagai penyangga, terdapat peralatan kotak kontrol diatasnya, kotak kontrol ini yang akan memberikan informasi setelah mendapatkan masukan dari sensor ketinggian air, diagram proses kinerja alat deteksi banjir secara dini disajikan pada gambar 2a dan desain alat disajikan pada gambar $2 \mathrm{~b}$. 


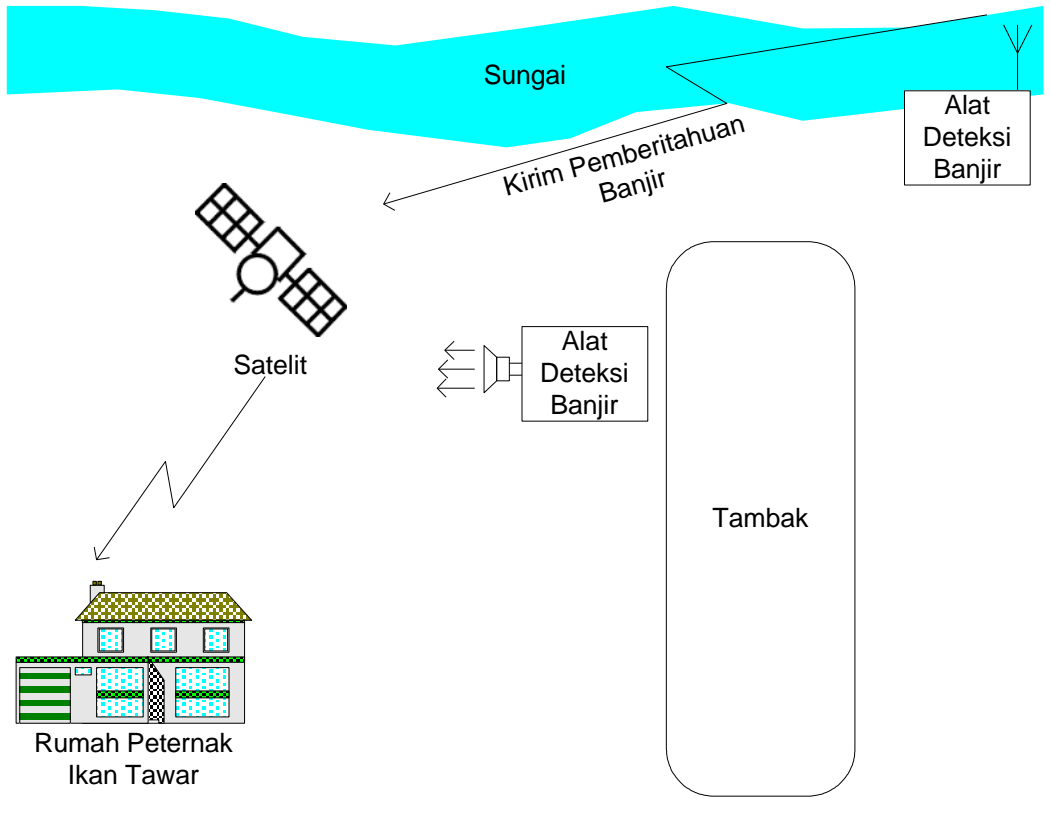

(a)

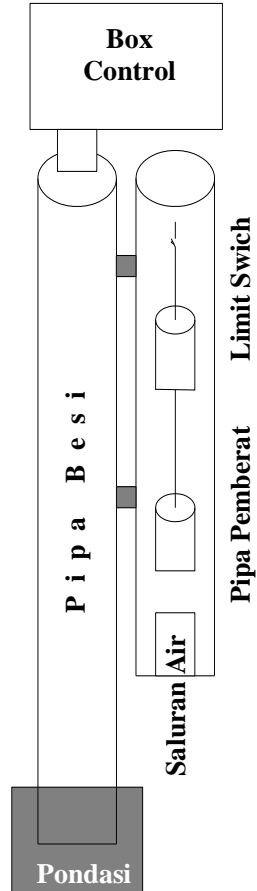

(b)

\section{Gambar 2. Diagram proses kinerja alat deteksi banjir secara dini}

Dengan menggunakan desain tersebut (gambar 2a), nantinya peternak ikan tawar dapat mengetahui banjir secara dini kapanpun dan dimanapun tanpa harus berada ditambak mereka. Selain itu dengan hadirnya alat deteksi banjir secara dini (gambar 2b) ini diharapkan kerugian peternak ikan tawar pada desa Temulus Kabupaten Kudus akibat tergenangnya air pada tambak mereka yang menyebabkan ikan mereka terlepas tidak terjadi lagi, sehingga harapannya peternak tidak mengalami kerugian akibat banjir.

\section{KESIMPULAN}

Berdasarkan hasil dan pembahasan deteksi banjir secara dini untuk mengurangi kerugian kelompok peternak ikan tawar di Desa Temulus Kecamatan Mejobo Kabupaten Kudus, mulai tahap awal hingga ahir, dapat ditarik kesimpulan bahwa penelitian ini menghasilkan sebuah desain alat deteksi banjir secara dini yang dapat dimanfaatkan oleh kelompok peternak ikan tawar di Desa Temulus Kecamatan Mejobo Kabupaten Kudus dengan harapan dapat mengurangi kerugian peternak ikan tawar akibat banjir. Penelitian ini juga dapat menjadi materi referensi bagi peneliti sejenis untuk mengembangkan alat yang lebih mutahir sesuai kebutuhan obyek penelitian dan dengan kemajuan teknologi yang ada.

\section{SARAN}

Penelitian ini telah menghasilkan suatu desain alat deteksi banjir secara dini, namun untuk pemasangan alat maupun penelitian selanjutnya masih memerlukan pengembangan dalam beberapa hal, yakni:

a. Penerapan alat perlu disesuaikan dengan lokasi atau obyek penelitian

b. Peralatan dan bahan dalam alat deteksi banjir ini membutuhkan tingkat akurasi dan presisi yang tinggi sehigga dalam pembuatannya membutuhkan ketelitian

c. Alat ini dipasang pada area yang mungkin jauh dari pemukiman sehingga keamanan peralatan wajib untuk diperhatikan.

\section{DAFTAR PUSTAKA}

[1] Khisan I.K. "Konsep Rancangan Pendeteksi Banjir Jarak Jauh Memanfaatkan Fasilitas Pesan Singkat (SMS)" Universitas Diponegoro, Semarang

[2] http://regional.kompas.com/read/2012/01/17/12433681/Desa, diakses tanggal 15 Juni 2010 pukul 09:00 
[3] http://www.suaramerdeka.com/v2/index.php/read/news_cetak/2014/02/07/190153/Jutaan-EkorIkan-Hanyut-Petambak-Rugi-Miliaran-Rupiah, diakses tanggal 15 Juni 2010 pukul 09:00

[4] Dachlan S.H. dkk "Sistem Penunjang Keputusan Deteksi Dini Bahaya Banjir Secara Real Time Menggunakan Data Logger Berbasis GSM”, Riset Andalan Perguruan Tinggi dan Industri (RAPID) Universitas Brawijaya, 2010.

[5] Pratomo I.F. dan Priyanto A "Rancang Bangun Perangkat Pendeteksi Banjir Pada Sungai Dengan Metode Fuzzy Menggunakan Jaringan Sensor Nirkabel”, STIKOM Surabaya

[6] Nugroho G.P. dkk "Sistem Pendeteksi Dini Banjir Menggunakan Sensor Keccepatan Air dan Sensor Ketinggian Air pada Mikrokontroler Arduino” Teknik Pomits Vol. 2 No. 1. 2013. Surabaya

[7] https://www.unisdr.org/we/inform/terminology, diakses tanggal 15 Juni 2010 pukul 09:00

[8] Peraturan Pemerintah Nomor 50 Tahun 2005 tanggal 16 November 2005 tentang "Penyelenggaraan Penyiaran Lembaga Penyiaran Swasta", pasal 17 ayat 10

[9] Dewi, Ika Fitriana dan Faizah, Nor (2007) "Perencanaan Pengendalian Banjir Sungai Sragi Lama Kabupaten Pekalongan (The Planning Of Flood Control Sragi Lama River in Pekalongan)". Undergraduate thesis, F. TEKNIK UNDIP. 